\title{
MODEL PEMBELAJARAN INOVATIF GURU SMA ABDUL HADI DENGAN STRATEGI LITERASI
}

\author{
${ }^{1}$ Rusli Ilham Fadli, ${ }^{2}$ Alfian Setya Nugraha, ${ }^{3}$ Resdianto Permata Raharjo, \\ ${ }^{4}$ Agus Sulton, ${ }^{5}$ Raras Hafiidah Sari \\ 1,2,3,4,5 Pendidikan Bahasa dan Sastra Indonesia FIP, Universitas Hasyim Asy’ari Tebuireng Jombang \\ ${ }^{1}$ rusliilhamfadli@gmail.com
}

\begin{abstract}
The purpose of this community service activity is to assist teachers in using the Innovative Learning Model with Literacy Strategy. This is one of the obligations of educators in order to solve social problems that have occurred in the community in the last period In addition, participants were also given the opportunity to discuss with the speakers and other participants. The purpose of Indonesian Language courses in accordance with the Content Standards Curriculum is that students have the ability: (1) to communicate effectively and efficiently in accordance with applicable ethics, both verbally and in writing; (2) respect and be proud to use Indonesian as the language of unity and national language; (3) understand Indonesian and use it appropriately and creatively for various purposes; and (4) use Indonesian to improve intellectual abilities, emotional and social maturity; (5) enjoy and utilize literary works to broaden horizons, refine character, and improve knowledge and language skills; (6) respect and boast of Indonesian literature as a cultural and intellectual treasure of Indonesian people. The scope of Indonesian Language courses in accordance with the competency-based curriculum includes the ability component which includes aspects of: (1) listening, (2) speaking, (3) reading and (4) writing.
\end{abstract}

Keywords: innovative, learning model, literacy

\begin{abstract}
Abstrak
Tujuan diadakannya kegiatan pengabdian kepada masyarakat ini adalah untuk mendampingi guru dalam menggunakan Model Pembelajaran Inovatif dengan Strategi Literasi. Hali ini merupakan salah satu kewajiban pendidik dalam rangka menyelesaikan permasalahan sosial yang dalam kurun waktu terakhir ini terjadi di masyarakat. Selain itu, peserta juga diberikan kesempatan untuk berdiskusi dengan para pemateri dan peserta yang lain. Tujuan Mata Kuliah bahasa Indonesia sesuai dengan Kurikulum Standar Isi adalah agar mahasiswa memiliki kemampuan: (1) berkomunikasi secara efektif dan efisien sesuai dengan etika yang berlaku, baik secara lisan maupun tulis; (2) menghargai dan bangga menggunakan bahasa Indonesia sebagai bahasa persatuan dan bahasa negara; (3) memahami bahasa Indonesia dan menggunakannya dengan tepat dan kreatif untuk berbagai tujuan; dan (4) menggunakan bahasa Indonesia untuk meningkatkan kemampuan intelektual, kematangan emosional dan sosial; (5) menikmati dan memanfaatkan karya sastra untuk memperluas wawasan, memperhalus budi pekerti, serta meningkatkan pengetahuan dan kemampuan berbahasa; (6) menghargai dan membanggakan sastra Indonesia sebagai khasanah budaya dan intelektual manusia Indonesia. Adapun ruang lingkup Mata Kuliah Bahasa Indonesia sesuai dengan kurikulum berbasis kompetensi mencakup komponen kemampuan yang meliputi aspek: (1) mendengarkan, (2) berbicara, (3) membaca dan (4) menulis.
\end{abstract}

Kata kunci: inovatif, literasi, model pembelajaran

\section{PENDAHULUAN}

Pendidikan adalah usaha sadar yang dengan sengaja dirancang untuk mencapai tujuan yang telah ditetapkan. Pendidikan bertujuan untuk meningkatkan kualitas sumber daya manusia. Salah satu usaha untuk meningkatkan kualitas sumber daya manusia ialah melalui proses pembelajaran di sekolah.

Dalam usaha meningkatkan kualitas sumber daya pendidikan, guru merupakan komponen sumber daya manusia yang harus dibina dan dikembangkan terus menerus. Potensi sumber daya guru itu perlu terus bertumbuh dan berkembang agar dapat melakukan fungsinya secara potensial. Selain itu pengaruh perubahan yang serba cepat mendorong guru guru untuk terus menerus belajar menyesuaikan diri dengan perkembangan ilmu pengetahuan dan teknologi serta mobilitas masyarakat.

Masyarakat mempercayai, mengakui dan menyerahkan kepada guru untuk mendidik tunas-tunas muda dan membantu 
mengembangkan potensinya secara professional. Kepercayaan, keyakinan, dan penerimaan ini merupakan substansi dari pengakuan masyarakat terhadap profesi guru. Implikasi dari pengakuan tersebut mensyaratkan guru harus memiliki kualitas yang memadai. Tidak hanya pada tataran normatif saja namun mampu mengembangkan kompetensi yang dimiliki, baik kompetensi personal, profesional maupun kemasyarakatan dalam selubung aktualisasi kebijakan pendidikan.

Berdasarkan uraian sebelumnya, dapat dirumuskan permasalahan sebagai berikut. 1) Bagaimana Proses Penerapan Model Pembelajaran Inovatif dengan Strategi Literasi di SMA Islam Abdul Hadi. 2) Bagaimana Kendala Penerapan Model Pembelajaran Inovatif dengan Strategi Literasi di SMA Islam Abdul Hadi. Mengacu pada permasalahan yang telah diuraikan sebelumnya, solusi diadakannya kegiatan pengabdian kepada masyarakat ini adalah memberikan kesadaran untuk mengunakan model pembelajaran inovatif dengan strategi literasi.

Kegiatan pengabdian kepada masyarakat ini dilaksanakan dengan menggunakan metode ceramah dan diskusi tentang Model Pembelajaran Inovatif dengan Strategi Literasi. Selain itu, peserta juga diberikan kesempatan untuk berdiskusi dengan para pemateri dan peserta yang lain.

Sebelum kegiatan pengabdian kepada masyarakat ini dilaksanakan, maka dilakukan persiapan yaitu: Mempersiapkan materi tentang Model Pembelajaran Inovatif dengan Strategi Literasi, dan Menentukan waktu pelaksanaan kegiatan

Kegiatan pengabdian kepada masyarakat ini dilaksanakan selama 2 (dua) hari, yaitu hari Rabu s.d. Kamis, 30 s.d. 31 Oktober 2019 yang beralamat di Jalan Mbecek Desa Ngudirejo Kecamatan Diwek Kabupaten Jombang, tepatnya di SMA Islam Abdul Hadi Diwek Jombang. Sasaran dari kegiatan ini adalah guru di SMA Islam Abdul Hadi Diwek Jombang yang berjumlah \pm 20 orang. Kegiatan ini dilaksanakan di SMA Islam Abdul Hadi Diwek Jombang.

Pengabdi merasa perlu untuk memperbaiki kondisi di masyarakat berkaitan dengan Model Pembelajaran Inovatif dengan Strategi Literasi. Kinerja pengabdian kepada masyarakat PT dapat menumbuhkan keterampilan menggunakan Model Pembelajaran Inovatif dengan Strategi Literasi oleh guru melalui penugasan menerapkan Model Pembelajaran Inovatif dengan Strategi Literasi yang dikerjakan oleh guru SMA Islam Abdul Hadi dengan harapan terciptanya budaya menerapkan Model Pembelajaran Inovatif dengan Strategi Literasi di SMA Islam Abdul Hadi Diwek Jombang. Pengabdian kepada masyarakat ini menggunakan metode ceramah dan praktik. Melalui kegiatan tersebut masalah-masalah Model Pembelajaran Inovatif dengan Strategi Literasi dapat dikaji, ditingkatkan dan dituntaskan, sehingga diharapkan dapat menciptakan sebuah budaya belajar (learning culture) di kalangan guru di SMA Islam Abdul Hadi Diwek Jombang.

Tindakan yang dilakukan oleh pengabdi adalah mengadakan apresiasi berupa tanya jawab tentang berbagai model pembelajaran inovatif yang digemari para guru. Tujuan dari apresiasi ini adalah menggali pengetahuan dan pengalaman guru tentang berbagai macam Model Pembelajaran Inovatif dengan Strategi Literasi yang pernah dilihat dan memberikan penjelasan mengenai kegiatan belajar mengajar yang hendak dilaksanakan, yaitu mengenai penerapan Model Pembelajaran Inovatif dengan Strategi Literasi melalui teknik pengandaian diri sebagai tokoh dalam cerita dengan media audio visual.

Gerakan Literasi Sekolah adalah sebuah gerakan dalam upaya menumbuhkan budi pekerti siswa yang bertujuan agar siswa memiliki budaya membaca dan menulis sehingga tercipta pembelajaran sepanjang hayat. Kegiatan rutin ini dilaksanakan untuk menumbuhkan minat baca peserta didik serta 
meningkatkan keterampilan membaca. Materi baca berisi nilai-nilai budi pekerti, berupa kearifan lokal, nasional, dan global yang disampaikan sesuai tahap perkembangan peserta didik.

Gerakan Literasi Sekolah ini merupakan upaya menyeluruh yang melibatkan semua warga sekolah baik guru, peserta didik, orang tua/wali murid, dan masyarakat, sebagai bagian dari ekosistem pendidikan sehingga membutuhkan dukungan kolaboratif berbagai elemen. Upaya yang ditempuh untuk mewujudkannya berupa pembiasaan membaca yang dilakukan dengan kegiatan 15 menit membaca. Guru membacakan buku dan warga sekolah membaca dalam hati.

Literasi lebih dari sekadar membaca dan menulis, namun mencakup keterampilan berpikir menggunakan sumber-sumber pengetahuan dalam bentuk cetak, visual, dan auditori. Di abad 21 ini, kemampuan ini disebut sebagai literasi informasi.

Hakikat pembelajaran keterampilan berbahasa memang berorientasi pada pelatihan penggunaan bahasa dan pada siswa sebagai subyek belajar. Tujuan primer pembelajaran keterampilan berbahasa Indonesia adalah peningkatan kemampuan siswa dalam penggunaan bahasa Indonesia untuk berbagai tujuan, keperluan dan keadaan (Budinuryanto dkk, 1998:141). Hal tersebut sesuai dengan salah satu tujuan mata pelajaran bahasa Indonesia yang menyatakan bahwa belajar pada hakikatnya adalah belajar berkomunikasi. Oleh karena itu, pembelajaran bahasa Indonesia diarahkan untuk meningkatkan kemampuan siswa dalam berkomunikasi dengan bahasa Indonesia, baik secara lisan maupun tertulis. Hal itu dikemukakan di dalam kurikulum (Depdiknas, 2006:231).

Dalam kegiatan menulis, siswa perlu disadarkan bahwa ada berbagai kemungkinan cara penataan atau penyusunan kata. Oleh karena itu, penting sekali siswa mendapat kesempatan saling membaca hasil tulisan sesama teman. Dalam kegiatan menulis termasuk kegiatan menemukan kesalahan dalam menulis (dalam berbagai bidang : ejaan, tanda baca, kelengkapan dan kejelasan kalimat, pemilihan kata) dan cara memperbaikinya (Purwo, 1997:7-8).

Rogers dan Shoemaker mengartikan inovasi sebagai ide-ide baru, praktek-praktek baru, atau objek-objek yang dapat dirasakan sebagai sesuatu yang baru oleh individu atau peserta didik. Pengertian baru disini mengandung makna bukan sekadar baru diketahui oleh pikiran (cognitife), melainkan juga baru karena belum dapat diterima secara luas oleh seluruh peserta didik dalam arti sikap (attitude) dan juga baru dalam pengertian belum diterima dan diterapkan oleh peserta didik. Pembelajaran inovatif adalah pembelajaran yang dikemas oleh pebelajar atas dorongan gagasan barunya yang merupakan produk dari learning how to learn untuk melakukan langkah-langkah belajar, sehingga memperoleh kemajuan hasil belajar.

Pembelajaran inovatif juga mengandung arti pembelajaran yang dikemas oleh guru atau instruktur lainnya yang merupakan wujud gagasan atau teknik yang dipandang baru agar mampu menfasilitasi siswa untuk memperoleh kemajuan dalam proses dan hasil belajar.

Strategi literasi melalui pembelajaran sastra dapat dilakukan dengan berbagai cara pada berbagai level pendidikan dan kepentingan. Pengajar sasra selalin memahami berbagai genre sastra juga mampu menyampaikan nilai-nilai religiusitas, humanitas, multikuturalitas kepada pembelajar. Dengan demikian mereka menjadi tertarik untuk mempelajari sastra. Pemilihan bahan ajar disesuaikan dengan kematangan usia, tingkat kesulitan, dan konteks pembelajaran. Kegiatan literasi sastra dilakukan dengan memanfaatkan berbagai media,baik melalui kegiatan lomba penulisan, penugasan merespon kembali teks yang dibaca, dan mengunggah di berbagai media.

Berdasarkan data dari World's Most Literate Nations yang dilakukan oleh Central 
Connecticut State University tahun 2016, Indonesia menempati urutan ke-60 dari 61 negara partisipan survei dalam hal kemampuan literasi (Miller \& McKenna, 2016). Sementara berdasarkan hasil tes Progress International Reading Literacy Study (PIRLS) tahun 2011, kemampuan membaca peserta didik di Indonesia berada di peringkat ke-45 dari 48 negara sedangkan survei yang dilakukan Programme for International Student Assessment (PISA) pada tahun 2015, menempatkan Indonesia di urutan ke-61 dari 72 negara partisipan survey (OECD, 2018). Data Perpustakaan Nasional tahun 2017, frekuensi membaca orang Indonesia rata-rata hanya tiga sampai empat kali per minggu (Pratiwi, 2018). Sementara jumlah buku yang dibaca rata-rata hanya lima hingga sembilan buku per tahun. Hasil dari berbagai survei tersebut menunjukkan bahwa literasi merupakan masalah yang serius dalam dunia pendidikan di Indonesia.

Salah satu respons pemerintah terhadap era globalisasi dan pentingnya literasi ini dapat terlihat dari program Gerakan Literasi Sekolah (GLS) yang gencar disosialisasikan dan diimplementasikan di banyak sekolah di Indonesia. Di dalam Buku Saku Gerakan Literasi Sekolah (Satgas, 2016), konsep literasi dibahas berdasarkan enam kategori yaitu literasi dini, literasi dasar, literasi perpustakaan, literasi media, literasi teknologi, dan literasi visual. Selain keenam jenis literasi ini, salah satu penulis di bidang literasi, Hoggart (1998, p. 56) berpendapat bahwa memiliki konvensional literasi, atau yang selama ini lebih dikenal dengan kemampuan literasi dasar dalam menulis, membaca, dan berhitung tidaklah cukup, saat ini dibutuhkan kemampuan literasi kritis atau yang lebih dikenal dengan critical literacy untuk terlibat secara aktif di era globalisasi. Literasi kritis juga menjadi salah satu aspek literasi yang kami sadari sangat penting dimiliki oleh anak muda Indonesia di era serba terbuka dan digital saat ini. Apalagi melalui Kurikulum 2013, peserta didik dituntut untuk lebih aktif mencari informasi demi memperdalam pengetahuan mereka. Tentu saja keaktifan ini perlu dibarengi dengan kemampuan memahami teks secara kritis agar mereka dapat menyaring berbagai informasi yang tersedia, baik yang berasal dari sumber terpercaya maupun tidak.

Seiring dengan program pemerintah yang sedang gencar mengimplementasikan gerakan literasi dalam pelaksanaan kurikulum 2013, Divisi Kajian Komisi Pendidikan PPI Dunia dengan ini ingin turut berkontribusi dalam peningkatkan kualitas kompetensi literasi khususnya dan peningkatan mutu pendidikan Indonesia umumnya. Berdasarkan latar belakang permasalahan yang sudah dibahas sebelumnya, Divisi Kajian Komisi Pendidikan PPI Dunia berharap dapat membuat kajian mengenai literasi dan implementasinya di indonesia dalam bentuk White Paper. White paper dianggap dapat menjadi rekomendasi bagi pemerintah Indonesia dalam memberi gagasan dalam upaya meningkatkan kemampuan literasi masyarakat Indonesia.

\section{METODE}

Kegiatan pengabdian kepada masyarakat ini dilaksanakan dengan menggunakan metode ceramah dan diskusi tentang Model Pembelajaran Inovatif dengan Strategi Literasi. Selain itu, peserta juga diberikan kesempatan untuk berdiskusi dengan para pemateri dan peserta yang lain.

Kegiatan pengabdian kepada masyarakat ini dilaksanakan selama 3 (tiga) hari, yang beralamat di Jalan Mbecek Desa Ngudirejo Kecamatan Diwek Kabupaten Jombang, tepatnya di SMA Islam Abdul Hadi Diwek Jombang.

Sasaran dari kegiatan ini adalah guru di SMA Islam Abdul Hadi Diwek Jombang yang berjumlah \pm 20 orang. Kegiatan ini dilaksanakan di SMA Islam Abdul Hadi Diwek Jombang.

Pengabdi merasa perlu untuk 
memperbaiki kondisi di masyarakat berkaitan dengan Model Pembelajaran Inovatif dengan Strategi Literasi. Kinerja pengabdian kepada masyarakat PT dapat menumbuhkan keterampilan menggunakan Model Pembelajaran Inovatif dengan Strategi Literasi oleh guru melalui penugasan menerapkan Model Pembelajaran Inovatif dengan Strategi Literasi yang dikerjakan oleh guru SMA Islam Abdul Hadi dengan harapan terciptanya budaya menerapkan Model Pembelajaran Inovatif dengan Strategi Literasi di SMA Islam Abdul Hadi Diwek Jombang. Pengabdian kepada masyarakat ini menggunakan metode ceramah dan praktik. Melalui kegiatan tersebut masalah-masalah Model Pembelajaran Inovatif dengan Strategi Literasi dapat dikaji, ditingkatkan dan dituntaskan, sehingga diharapkan dapat menciptakan sebuah budaya belajar (learning culture) di kalangan guru di SMA Islam Abdul Hadi Diwek Jombang.

Tindakan yang dilakukan oleh pengabdi adalah mengadakan apresiasi berupa tanya jawab tentang berbagai model pembelajaran inovatif yang digemari para guru. Tujuan dari apresiasi ini adalah menggali pengetahuan dan pengalaman guru tentang berbagai macam Model Pembelajaran Inovatif dengan Strategi Literasi yang pernah dilihat dan memberikan penjelasan mengenai kegiatan belajar mengajar yang hendak dilaksanakan, yaitu mengenai penerapan Model Pembelajaran Inovatif dengan Strategi Literasi melalui teknik pengandaian diri sebagai tokoh dalam cerita dengan media audio visual.

Gerakan Literasi Sekolah adalah sebuah gerakan dalam upaya menumbuhkan budi pekerti siswa yang bertujuan agar siswa memiliki budaya membaca dan menulis sehingga tercipta pembelajaran sepanjang hayat. Kegiatan rutin ini dilaksanakan untuk menumbuhkan minat baca peserta didik serta meningkatkan keterampilan membaca. Materi baca berisi nilai-nilai budi pekerti, berupa kearifan lokal, nasional, dan global yang disampaikan sesuai tahap perkembangan peserta didik.

Gerakan Literasi Sekolah ini merupakan upaya menyeluruh yang melibatkan semua warga sekolah baik guru, peserta didik, orang tua/wali murid, dan masyarakat, sebagai bagian dari ekosistem pendidikan sehingga membutuhkan dukungan kolaboratif berbagai elemen. Upaya yang ditempuh untuk mewujudkannya berupa pembiasaan membaca yang dilakukan dengan kegiatan 15 menit membaca. Guru membacakan buku dan warga sekolah membaca dalam hati.

Literasi lebih dari sekadar membaca dan menulis, namun mencakup keterampilan berpikir menggunakan sumber-sumber pengetahuan dalam bentuk cetak, visual, dan auditori. Di abad 21 ini, kemampuan ini disebut sebagai literasi informasi

\section{HASIL DAN PEMBAHASAN}

Kegiatan pengabdian kepada masyarakat ini dilaksanakan selama 3 (tiga) hari, yang beralamat di Jalan Mbecek Desa Ngudirejo Kecamatan Diwek Kabupaten Jombang, tepatnya di SMA Islam Abdul Hadi Diwek Jombang.

Sasaran dari kegiatan ini adalah guru di SMA Islam Abdul Hadi Diwek Jombang yang berjumlah \pm 20 orang. Kegiatan ini dilaksanakan di SMA Islam Abdul Hadi Diwek Jombang.

Pembelajaran inovatif juga mengandung arti pembelajaran yang dikemas oleh guru atau instruktur lainnya yang merupakan wujud gagasan atau teknik yang dipandang baru agar mampu menfasilitasi siswa untuk memperoleh kemajuan dalam proses dan hasil belajar. Pembelajaran konvensional boleh dikatakan hampir tidak pernah dilaksanakan, mengingat konsep pembelajaran sekarang apapun metode dan alat pembelajarannya mengacu pada siswa sebagai subyek pembelajaran. Pembelajaran inovatif ini tidak lepas dari rencana pembelajaran yang harus sesuai dengan silabus dan RPPnya. Intinya pembelajaran harus terencana terkendali menurut rencana 
pembelajaran yang dibuat guru pada awal semester.

Pembelajaran ini diharapkan dapat hasil belajar siswa agar menjadi lebih baik, yaitu dengan bukti fisik nilai siswa. Tetapi pembelajaran sekarang bukan itu intinya. Kurikulum KTSP sekarang lebih menekankan pada prosesnya, bukan hasilnya, artinya bagaimana agar siswa yang semula tidak tahu menjadi mengerti. Ini lebih baik dari pada peningkatan hasil yang dimanipulatif. Terpenting, selama angka-angka masih menjadi indikator, pendidikan Indonesia yang baik hanya akan menjadi mimpi.

Gerakan Literasi Sekolah adalah sebuah gerakan dalam upaya menumbuhkan budi pekerti siswa yang bertujuan agar siswa memiliki budaya membaca dan menulis sehingga tercipta pembelajaran sepanjang hayat. Kegiatan rutin ini dilaksanakan untuk menumbuhkan minat baca peserta didik serta meningkatkan keterampilan membaca. Materi baca berisi nilai-nilai budi pekerti, berupa kearifan lokal, nasional, dan global yang disampaikan sesuai tahap perkembangan peserta didik.

Gerakan Literasi Sekolah ini merupakan upaya menyeluruh yang melibatkan semua warga sekolah baik guru, peserta didik, orang tua/wali murid, dan masyarakat, sebagai bagian dari ekosistem pendidikan sehingga membutuhkan dukungan kolaboratif berbagai elemen. Upaya yang ditempuh untuk mewujudkannya berupa pembiasaan membaca yang dilakukan dengan kegiatan 15 menit membaca. Guru membacakan buku dan warga sekolah membaca dalam hati.

Literasi lebih dari sekadar membaca dan menulis, namun mencakup keterampilan berpikir menggunakan sumber-sumber pengetahuan dalam bentuk cetak, visual, dan auditori. Di abad 21 ini, kemampuan ini disebut sebagai literasi informasi.

Berbagai upaya dilakukan oleh pemerintah melalui Kemendikbud dan Kemenristekdikti untuk meningkatkan literasi bangsa. Di masa pemerintahan Presiden Soeharto ada gerakan tradisi tulis dan bulan buku dan gemar membaca, dengan berbagai event nasional seperti gerakan penumbuhan minat baca dan bulan bahasa. Saat ini sedang gencar diprogramkan Gerakan Literasi Sekolah (GLS). Dibentuk Satgas GLS oleh Direktorat Pendidikan Dasar agar bangsa Indonesia memiliki tingkat membaca yang tinggi. Di sekolah, di kampus, dan di masyarakat digelorakan srategi penumbuhan literasi. Apakah sastra sebagai produk budaya berkontribusi dalam membangun literasi bangsa, walaupun penilaian kemampuan membaca siswa Indonesia masih rendah menurut penilaian PISA. Strategi yang dilakukan melalui pembelajaran sastra agar siswa memiliki minat baca dan menulis kembali karya yag dibaca dengan bahasa sendiri. Atmosfer pembelajarn yang menyebabkan siswa memiliki antusias untuk membaca karya sastra. Ketersediaan bukubuku sastra, terciptanya atmosfer pembelajaran sastra, guru berperan sebagai model membacadan menuis karya sastran sebagai parameter keberhasilan pembelajara sstra. Guru mampu memilihkan meteri pembelajaran sastra yang sesuai dengan tingkat intelektual dan usia siswa dan mampu menyiarkan karya sastra dalam berbagai media.

Gerakan literasi sekolah (GLS) yang sedang populer diinisiasi oleh Kemendikbud saat ini sebenarnya sudah dimulai tiga dasawarsa yang lalu oleh Presiden Soeharto melalui gerakan tradisi tulis dan bulan buku dan gemar membaca. Setelah lebih dari tiga dasawarsa, pencanangan tradisi baca-tulis tersebut hasilnya jauh dari memuaskan.Studi yang dirilis dilakukan PIRLS (Progress in International Reading and Literary Study) yang menempatkan Indonesia ranking 42 dari 55 negara, studi yang dilakukan PISA (Programe International Student Assessment, 2013 ) Indonesia menempati posisi 62 dari 69 negara membuat dunia pendidikan tersentak. Kondisi demikian memacu dunia pendidikan untuk 
berbenah. Begitu pentingnya budaya literasi yang kemudian merambah pada literasi di berbagai bidang seperti gerakan literasi sekolah (GLS) dan turunan literasi lain seperti literasi kesehatan, keuangan, transportasi, sains teknologi informasi dan komunikasi, literasi sastra dan lainlain.

Apakah kita harus risau bahwa literasi bangsa Indonesia demikian lemah seperti digambarkan oleh peneliti asing. Apakah kita tidak mencermati fakta bahwa anak-anak kita masih memiliki minat belajar yang tinggi seperti digambarkan dalam Novel Laskar Pelangi dan Negeri Lima Menara? Tidakkah kita mendengarkan merdunya suara orang mengaji di surau atau Masjid di saat subuh. Apakah kita tidak mendengarn orang Jawa melantunkan kidung dan mocopat yang penuh dengan pembelajaran etika religi dan humanisme? Apakah kita tidak menyaksikan masih banyak relawan pustaka yang meminjamkan buku gratis kepada anak-anak yang antusias membaca di perpustakaan keliling, di perpustakaan desa, pojok baca, di kampung-kampung dan di kota?. Rendahnya kemampuan literasi bangsa perlu disikapi dengan merawat, memupuk kemampuan literasi dalam berbagai bidang dengan upaya nyata, baik di kelas maupun di luar kelas, di rumah maupun di luar rumah di lembagalembaga dengan melibatkan semua pihak.

$$
\text { Pemerintah sudah berusaha }
$$

menumbuhkambangkan persoalan literasi dengan berbagai regulasi. Menteri Pendidikan dan Kebudayaan Kabinet Kerja mengeluarkan Permen Nomor 23 Tahun 2015 tentang Penumbuhan Budi Pekerti. Dalam pengembangan potensi diri anak didik, sekolah memfasilitasi siswa dengan melakukan kegiatan wajib (1) menggunakan 15 menit sebelum hari pembelajaran untuk membaca buku selain buku matapelajaran (setiap hari) dan (2) seluruh warga sekolah (guru, tenaga kependidikan, siswa) memanfaatkan waktu sebelum mulai hari pembelajaran pada harihari tertentu untuk kegiatan olah fisik seperti senam kesegaran jasmani, sekurangkurangnya dilaksanakan satu kali dalam seminggu. Dari 2 butir Surat Keputusan Menteri tersebut Nampak pembangunan intelektual dan fisik wajib dilaksanakan para program persekolahan.

Persoalannya adalah jenis bacaan apa yang diperuntukkan siswa dan guru, apakah jenis bacaan sastra, filsafat, agama, biografi, kreatrivitas, tokoh penemu, sains, soaial, kemasyarakatan. Jenis bacaan apa yang sesuai dengan umur para pembaca?, bagaimana pengadaan koleksi buku tersebut? Apakah guru bisa berperan sebagai model pembaca? Hal ini menjadi penting karena guru-guru kita pun belum menjadi model pembaca yang baik. Studi yang dilakukan Taufik Ismail (2002) bahwa siswa belum banyak membaca karya sastra.

Sastra selalu didefinisikan tulisan yang indah, dengan konsekuensi menggunakan stilistika untuk membangkitkan imajinasi bagi pembacanya. Mengenai pernyataan normatif sastra dan pengajaran Putu Wijaya (2009) menulis. Bagaimana sebaiknya mengajarkan sastra? Itu bukan pertanyaan pertama yang harus dijawab oleh seorang guru sastra. Karena mula-mula yang harus dijawabnya adalah: apakah sastra itu? Kemudian, menyusul pertanyaan: apa yang dimaksudkan dengan mengajarkan? Dapatkah sastra diajarkan? Lalu siapa saja yang hendak dibelajarkannya pada sastra.

Mengenai karya sastra Putu memberikan definisi berikut ini. Sastra dalam pemahaman saya, adalah segala bentuk ekspresi dengan memakai bahasa sebagai basisnya. Dengan membuat kapling yang begitu lebar dan umum, maka kita seperti menjaring ikan dengan pukat harimau. Bukan hanya apa yang tertulis, apa yang tidak tertulis pun bisa masuk dalam sastra. Tidak hanya yang su (indah), catatancatatan, surat-surat, renungan, berita-berita, apalagi cerita dan puisi, anekdot, graffiti, bahkan pidato, doa dan pernyataan-pernyataan, apabila semuanya mengandung ekspresi, itu 
adalah sastra.

Dengan memandang sastra dengan kaca mata lebar seperti itu, lingkup sastra mendadak membludak menyentuh segala sektor kehidupan. Tidak ada satu sudut kehidupan pun yang tidak mempergunakan bahasa sebagai alat komunikasinya. Segala hal kena gigit oleh sastra. Teknologi dan dagang pun tak mampu bebas dari sastra. Dengan kata lain, tak ada bidang yang tak terkait dengan sastra. Karenanya, bila sastra tiba-tiba menjadi sesuatu yang terisolir dalam kehidupan, pasti ada sesuatu yang telah sesat . Termasuk kesesatan dalam mengajarkan sastra itu sendiri.

Apa yang disampaikan Putu Wijaya, membuka mata para guru sastra di Sekolah, bahwa sastra tidak bisa berdiri sendiri, seagai materi pengajaran sastra, tetapi selalu berkait dengan ekspresi dalam bentuk bahasa. Sastra erat hubungannya dengan imajinasi seseorang. Apa yang anda saksikan dari sebuah iklan rokok, ketika seorang anak muda berdesakdesakan di gerbong kereta api untuk mencari tempat duduk. Setelah berhasil duduk, ada seorang ibu tua yang tidak mendapat tempat duduk, lalu si pemuda memberi tempat duduknya, sedang laki-laki lain yang duduk di depannya menutup matanya dengan Koran. Pembelajaran moral apa yang didapat dari tayangan iklan tersebut bagi pembelajaran moral? Meminjam istilah Rene Wellek dan Austin Waren (1990), satra memiliki kebermanfaatan dan kenikmatan. Alangkah indahnya jika banyak pemuda di Indonesia mau berkorban untuk orang lain dalam konteks yang lebih luas.

Dalam hubunganya dengan guru sastra Putu Wijaya (2009) menulis, Pada prakteknya, seorang guru di masa lalu, adalah seorang "penghajar". Ia memiliki posisi lebih tahu, lebih cerdik, lebih pintar dan lebih berkuasa . Untuk mengoper ilmu yang dikuasainya (padahal sering ilmu yang sudah kedaluwarsa), ia tak segan-segan melakukan kekerasan dengan dalih desiplin. Suasana kelas lebih merupakan pertunjukan monolog dan indoktrinasi tanpa boleh ada yang membantah. Yang terjadi bukan proses pembelajaran tetapi penderaan. Murid-murid disiksa untuk menelan, menghapal, apa yang dimuntahkan oleh guru. Berpendapat lain bisa dicap kurangajar. Hasil pembelajaran seperti itu memang tak menghalangi anak-anak yang jenius untuk tumbuh terus dan melejit berdasarkan kodratnya. Tetapi secara umum, posisi guru yang menghajar itu sudah menyelewengkan makna pembelajaran menjadi pelajaran mengembik. Murid-murid hapal namanama, tahun dan jumlah, tetapi tak mampu memaknakan apa hakekat dari semua pengetahuan yang diterimanya.

Murid yang terdidik bertahun-tahun bukannya menjadi luas wawasannya dan kaya gagasannya, tetapi malah menjadi berkepala keras dan pada gilirannya, mentoladan jejak gurunya, menjadi otoriter. Secara umum UNESCO mendefinisikan literasi sebagai kemampuan seseorang menulis dan membaca. Literasi juga mengintegrasikan kemampuan menyimak, berbicara, membaca, menulis, dan berpikir kritis (Baynham, 1995:5). Sebagai piranti komunikasi, Liteasi dapat dianalogikan sebuah mata rantai antarketeampilan berbahasa yang tidak terpisahkan. Keterkaitan antara membaca dan menulis seperti dua sisi mata uang. (Klein, dkk (1991)Orang yang dapat menulis dengan baik akan cenderung memiliki kemamuan membaca yang baik. Sebaliknya, orng yang memiliki kemampuan membaca yang baik cenderung dapat menjadi penulis yang baik.

Bagaimana denga literasi sastra? Literasi sastra dapat dimaknai sebagai kemampuan baca-tulis di bidang sastra. Kemampuan bacatulis sasra dapat disamakan membaca sastra dan menulis sastra. Membaca merupakan keterampilan membaca dengan objek karya sastra berupa puisi, fiksi maupun naskah drama. Demikian pula menulis sastra menghasilkan tulisan dalam bentuk karya sastra. Membaca sastra merupakan kegiatan 
sederhana sekaligus kompleks. Bagi pembaca awam membaca hanya untuk keperluan rekreasi saja. Sebaiknya bagi pembaca serius (mahasiswa sastra dan guru sastra), membaca sastra adalah sangat kompleks. Dalam membaca sastra dimulai dengan persiapan memilih karya sastra, ketersediaan waktu dan tempat. Pada saat membaca perlu menafsiran lambing dan simbol dalam teks, menganalisis, menyintensiskan, kemudian menyimpulkan pesan dalam teks sastra. Pada saat membaca dan memaknai teks pembaca akan memperoleh "Kenikmatan" dan "manfaat" dari teks tesebut. Cara yang sederhana untuk mengukur bahwa siswa memperoleh manfaat dilakukan dengan cara menukis kembali cerita terebut. Pada tataran kuliah pengajaran sastra mahasiswa dapat memberi komentar kritis berupa puisi, fiksi, naskah drama, bahkan esai kritik sastra.

Pengetahuan mengenai teori sastra, pendekatan teks satra, pengetahuan tentang karya sastra, pengalaman tentang kehidupan kultural, estetik, moral yang dimiliki mahasiswa dapat diwujudkan dalam bentuk karya yag baru, baik melalui alih wahana maupun ekranisasi. Pembeajaran Sastra di tingkat sekolah tidak bertujuan menciptakan ahli sastra tetapi memberi motivasi kepada siswa untuk mencintai karya sastra dan pada akhirnya mereka kecanduan membaca karya sastra. Kegiatan membaca sasra pada akhirnya mendorong siswa untuk memiliki minat membaca di berbagai bidang. Oleh karena itu, guru astra di sekolah berperan sebagai role model pembelajar sastra. Guru sastra memiliki jam membaca karya sastra baik dalam hal kuantitas dan kuaitas. Minimal hafal beberapa novel-novel serius maupun hafal beberapa cerpen dan puisi. Guru juga menjadi model pembaca puisi dan aktor yang baik dalam memerankan tokoh dalam naskah drama. Oleh karena itu, selain mengajar bahasa dan sastra Indonesia, guru sastra di sekolah juga teribat dalam kegiatan bersasatra baik dalam hal menulis karya sastra mauun dalam kegiatan budaya lainnya. Guru sanggup memompakan semangat religiusitas dan humanitas melalui teks-teks sastra.

Strategi literasi melalui pembelajaran sastra dapat dilakukan dengan berbagai cara pada berbagai level pendidikan dan kepentingan. Pengajar sasra selalin memahami berbagai genre sastra juga mampu menyampaikan nilai-nilai religiusitas, humanitas, multikuturalitas kepada pembelajar. Dengan demikian mereka menjadi tertarik untuk mempelajari sastra. Pemilihan bahan ajar disesuaikan dengan kematangan usia, tingkat kesulitan, dan konteks pembelajaran. Kegiatan literasi sastra dilakukan dengan memanfaatkan berbagai media,baik melalui kegiatan lomba penulisan, penugasan merespon kembali teks yang dibaca, dan mengunggah di berbagai media.

Ketika berbicara mengenai pengertian kata literasi, banyak pihak yang mendeskripsikannya dalam konteks baca tulis. Orang yang literate diartikan sebagai orang yang mampu membaca dan menulis, sedangkan orang yang illiterate diartikan sebagai orang yang tidak bisa membaca dan menulis atau disamakan dengan buta aksara/butu huruf. Pengertian yang sederhana mengenai literasi ini dirasakan dapat memberikan kesan bahwa persoalan literasi, terutama di Indonesia akan selesai ketika angka buta huruf menurun. Tentu saja, pemberantasan buta huruf merupakan salah satu agenda utama dalam menciptakan masyarakat Indonesia yang literat. Jika dilihat dari data angka buta huruf di Indonesia, memang angka buta huruf masyarakat Indonesia tergolong rendah jika dibandingkan dengan negara-negara berkembang lainnya. Kita patut berbangga hati karena program pemberantasan buta huruf yang gencar dijalankan pada zaman Presiden Suharto berjalan dengan baik (Antoro, 2017). Akan tetapi, jika kita mengkaji lebih lanjut pengertian literasi di berbagai jurnal, buku, laporan, tulisan baik akademis maupun kebijakan di tingkat nasional dan internasional, 
dapat dilihat bahwa pengertian literasi sudah menjadi lebih luas dan kompleks. Ini dikarenakan oleh perkembangan zaman dan pemahaman akan literasi yang sudah menjadi semakin dalam. Istilah literasi dalam bahasa latin disebut sebagai Literatus yang artinya adalah orang yang belajar. National Institute for Literacy menjelaskan bahwa literasi adalah kemampuan seseorang untuk membaca, menulis, berbicara, menghitung dan memecahkan masalah pada tingkat keahlian yang diperlukan dalam pekerjaan, keluarga dan masyarakat. Education Development Center (EDC) juga turut mengeluarkan pengertian dari literasi, yaitu kemampuan individu untuk menggunakan potensi serta skill yang dimilikinya, jadi bukan hanya kemampuan baca tulis saja. Lebih lanjut lagi, menurut UNESCO (2006), literasi merupakan keterampilan kognitif dalam membaca dan menulis yang tidak hanya terikat pada konteks sumber dan cara pemerolehan keterampilan tersebut. Hal ini disebabkan pemahaman literasi seseorang terpengaruh oleh kondisi akademis, lingkungan, unsur-unsur budaya, dan pengalaman orang tersebut. Dengan demikian, secara umum literasi berarti kemampuan seseorang untuk mengelola dan memahami informasi ketika membaca maupun menulis. Namun demikian, literasi tidak hanya terbatas pada kemampuan baca dan tulis saja sebab literasi berkaitan erat dengan keterampilan berbahasa yang membutuhkan kemampuan kognitif, pengetahuan tenatang jenis sumber bacaan yang dibaca beserta budaya yang melingkupinya. Pada saat ini, gerakan literasi mulai dikembangkan dan ditumbuhkan kepada seluruh masyarakat dengan harapan agar setiap orang dapat menggunakannya sebagai sarana untuk belajar sepanjang hayat. Dengan meningkatnya kemampuan literasi setiap individu masyarakat, diharapkan akan meningkat pula daya belajar masyarakat tersebut. Dengan demikian, diharapkan pula kualitas hidup masyarakat dapat meningkat.
Ada 6 jenis literasi yang dijabarkan dalam buku Desain Induk Gerakan Literasi Sekolah (Wiedarti \& Kisyani-Laksono, 2016a, p.8-9) untuk mencapai kompetensi literasi informasi yang baik di era digital dewasa ini:

Literasi Dini [Early Literacy (Clay, 2001)], yaitu kemampuan untuk menyimak, memahami Bahasa lisan, dan berkomunikasi melalui gambar dan lisan yang dibentuk oleh pengalamannya berinteraksi dengan lingkungan sosialnya di rumah. Pengalaman peserta didik dalam berkomunikasi dengan bahasa ibu menjadi fondasi perkembangan literasi dasar.

Literasi Dasar (Basic Literacy), yaitu kemampuan untuk mendengarkan, berbicara, membaca, menulis, dan menghitung (counting) berkaitan dengan kemampuan analisis untuk memperhitungkan (calculating), mempersepsikan informasi (perceiving), mengomunikasikan, serta menggambarkan informasi (drawing) berdasarkan pemahaman dan pengambilan kesimpulan pribadi.

Literasi Perpustakaan (Library Literacy), antara lain, memberikan pemahaman cara membedakan bacaan fiksi dan nonfiksi, memanfaatkan koleksi referensi dan periodikal, memahami Dewey Decimal System sebagai klasifikasi pengetahuan yang memudahkan dalam menggunakan perpustakaan, memahami penggunaan katalog dan pengindeksan, hingga memiliki pengetahuan dalam memahami informasi ketika sedang menyelesaikan sebuah tulisan, penelitian, pekerjaan, atau mengatasi masalah.

Literasi Media (Media Literacy), yaitu kemampuan untuk mengetahui berbagai bentuk media yang berbeda, seperti media cetak, media elektronik (media radio, media televisi), media digital (media internet), dan memahami tujuan penggunaannya.

Literasi Teknologi (Technology Literacy), yaitu kemampuan memahami kelengkapan yang mengikuti teknologi seperti peranti keras (hardware), peranti lunak (software), serta etika dan etiket dalam 
memanfaatkan teknologi. Berikutnya, kemampuan dalam memahami teknologi untuk mencetak, mempresentasikan, dan mengakses internet. Dalam praktiknya, juga pemahaman menggunakan komputer (Computer Literacy) yang di dalamnya mencakup menghidupkan dan mematikan komputer, menyimpan dan mengelola data, serta mengoperasikan program perangkat lunak. Sejalan dengan membanjirnya informasi karena perkembangan teknologi saat ini, diperlukan pemahaman yang baik dalam mengelola informasi yang dibutuhkan masyarakat.

Literasi Visual (Visual Literacy), adalah pemahaman tingkat lanjut antara literasi media dan literasi teknologi, yang mengembangkan kemampuan dan kebutuhan belajar dengan memanfaatkan materi visual dan audiovisual secara kritis dan bermartabat. Tafsir terhadap materi visual yang tidak terbendung, baik dalam bentuk cetak, auditori, maupun digital (perpaduan ketiganya disebut teks multimodal), perlu dikelola dengan baik. Bagaimanapun di dalamnya banyak manipulasi dan hiburan yang benar-benar perlu disaring berdasarkan etika dan kepatutan.

Hari Literasi Internasional yang dirayakan setiap tanggal 8 September ditetapkan oleh UNESCO sebagai momen untuk merayakan dan merefleksikan kembali progam-program berkaitan dengan pengembangan literasi sebagai bagian penting dari pembelajaran sepanjang hayat yang terdapat dalam Agenda Pendidikan 2030. Tahun 2017 lalu, UNESCO mengambil tema 'Literacy in a digital world' untuk merespons kebutuhan literasi di zaman serba digital saat ini. Dari tema ini, dapat kita lihat bagaimana dunia internasional melihat pentingnya untuk menggali strategi pengembangan kompetensi literasi yang mempertimbangkan pergeseran media informasi dari cetak/luring (offline) ke digital/daring (online). Seperti yang akan kita bahas nanti, kompetensi literasi digital dan media ini sejalan dengan kurikulum 2013 yang menekankan kepada integrasi berbagai jenis media dalam pembelajaran yang berpusat kepada peserta didik. Oleh karena itu, sangat penting ketika berbicara mengenai isu literasi untuk melihatnya dalam konteks dunia global dan digital (globalised dan digitalised world) yang dinamis dan tanpa batas. Dari buku "Desain Induk Gerakan Literasi Sekolah" yang ditulis dan dikeluarkan oleh Direktorat Jenderal Pendidikan Dasar Dan Menengah Kementerian Pendidikan Dan Kebudayaan (2016), dapat juga ditemukan bagaimana Pemerintah Indonesia menyampaikan bagaimana kemampuan baca tulis dalam artian konvensional sudah tidak tepat lagi. Dalam buku tersebut ditekankan pentingnya untuk mengembangkan "literasi informasi" yang terkait dengan "kemampuan untuk mengidentifikasi, menentukan, menemukan, mengevaluasi, menciptakan secara efektif dan terorganisasi, menggunakan dan mengomunikasikan informasi untuk mengatasi berbagai persoalan" (hal.1). Di dalam penjelasan ini tersirat makna pentingnya untuk mengembangkan kemampuan berpikir kritis agar peserta didik mampu mengakses informasi yang valid dengan menggunakan sumber yang dapat dipercaya, memverifikasi kebenaran sumber juga isi dari informasi yang didapat, dan mengerti makna dari informasi yang didapat.

\section{DAFTAR PUSTAKA}

Depdiknas. 2003. Sistem Pendidikan Nasional. Jakarta: Sekjend Depdiknas.

Depdiknas. 2006. Standar Isi. Jakarta: Depdiknas.

Miles, B. Matthew dan Hubberman, Michael

A. 1992. Analisis Data Kualitatif. Terjemahan Tjejep Rohendi. Jakarta: Universitas Indonesia Press.

Muchlisoh, dkk. 1992. Materi Pokok Pendidikan Bahasa Indonesia 2. Jakarta: Depdikbud.

Nataliasari. 2013. Analisis Kesalahan Ejaan pada Surat Dinas Di Balai Desa Butuh Krajan, Kecamatan Tengaran Kabupaten 
Semarang. Tesis tidak diterbitkan.

Semarang: Pascasarjana Universitas Negeri Semarang.

Purwo, Bambang Kaswanti. 1997. Pokokpokok Pengajaran Bahasa dan Kurikulum 1994. Bahasa Indonesia. Jakarta: Depdikbud.

Sabarti Akhadiah, Maidar G. Arsjad, Sakurra H. Ridwan. 1996. Pembinaan Kemampuan Menulis Bahasa Indonesia. Jakarta: Erlangga.

Sardiman, A.M. 1992. Interaksi dan Motivasi Belajar Mengajar. Jakarta: Rajawali.

Semi, Atar, M. 1990. Menulis Efektif. Padang: Angkatan Raya.

Sugiyono. 2010. Memahami Penelitian Kualitatif. Bandung ; CV. Alfabeta.

Suparno. 1998. Pengajaran Bahasa Indonesiadi Sekolah. Jakarta: Erlangga.

Supriyadi dkk. 1992. Materi Pokok Pendidikan
Bahasa Indonesia 2. Jakarta: Universitas Terbuka.

Suwandi, Sarwiji. 2001. Pelaksanaan Pengajaran di Sekolah Menengah Umum Berdasarkan Kurikulum 2004. Jakarta: Balitbang.

Trianto. 2007. Model-model Pembelajaran Inovatif Berorientasi Konstruktivistik. Jakarta: Depdikbud.

Trianto. 2008. Mendesain Pembelajaran Kontekstual (Contextual Teaching and Learning) di Kelas. Jakarta: Cerdas Pustaka Publisher.

Widodo Hs. Dkk. 1994. Pembelajaran Keterampilan Menulis Terpadu. Jakarta: Depdikbud.

Wiranataputra, Udin S. dkk. 2007. Teori Belajar dan Pembelajaran. Jakarta: Universitas Terbuka. 